\title{
INFLUENTIAL FACTORS ON CONSUMER PURCHASE INTENTIONS: CASES OF INSTANT NOODLE PRODUCTS IN THE HUNGARIAN MARKET
}

\author{
Csaba Janos Nagy \\ University of the Thai Chamber of Commerce, Thailand
}

\begin{abstract}
This research investigates the factors that impact consumer purchase intention towards instant noodle products in the Hungarian market. A comprehensive literature review indicates that there are five main factors that have impact on willingness to purchase instant noodle products, which is the measurement item to purchase intention towards instant noodle products. However, the results show that there are four main factors, which are packaging (appearance), product aspect of price (product price compared to average), promotion (drive, marketing communication) and convenience (decision-making process, time spent on preparing food, time spent on shopping). The research concludes that young (less than 35), single, lower educated (elementary school, high school or vocational/associate's degree) and below average or close to average (less than 100,000 HUF and $100,001-200,000$ HUF) net earners show the highest willingness to purchase. This consumer profile is to be targeted by business professionals to enhance purchasing of instant noodle products in Hungary.
\end{abstract}

Keywords: Consumer purchase intention, Willingness to purchase, Instant noodles, Europe, Hungary.

DOI: http://dx.doi.org/10.15549/jeecar.v5i2.244

\section{PROBLEM DEFINITION}

Preparing food at home in the kitchen has significantly decreased in time in several areas of Europe (Pleasanton, 1999). Mostly, the western part of the continent was the leader of adapting processed and ready meal products into their general diet (McCullough, Jones \& Vignali, 2003). The so called family meals such as a Monday night dinner with everyone at the table eating a home-cooked meal have nearly disappeared. The amount of times when people "munch on" something while they travel has increased. Also, time spent outside of home has become greater compared to the 1990s and 2000s. Some of the time consuming activities that force this pattern include working out at a gym, getting a fashion or beauty treatment and even just taking to or picking up children from school and other extracurricular activities (McCullough et al., 2003).

The fact that in the USA more than one thousand packaged food products are being launched every month shows the strength and power of convenience foods (Buckley, Cowan \& McCarthy, 2007). These types of products have taken control of a general consumer's everyday life. The reasons behind this takeover most likely come from three factors which contribute to "convenience" itself. These are time, physical energy and mental energy. Time is explained as heavy importance for people who seek it a lot more due to their broken down mealtimes, solitary meals and individualism in consumption patterns. Physical energy is part of 
convenience as taking the effort to plan and go shopping or prepare food at home. While mental energy includes lifestyle standards among consumers such as female participation in labor force, thinking of healthy eating or individualism (Buckley et al., 2007).

For general consumers in the food industry, who are between 18-45 years of age and either work or study full-time, convenience in the kitchen is really important. Instant snacks and ready-to-eat food products satisfy this need because they do not require more than 5 minutes of preparation time. Also, the consumer is not required to be there for the preparation because other than finding a bowl, opening the product and putting the water on the stove or in the water heater, the process works by itself. Therefore, the consumer can even use those few minutes to multitask. This is appealing for students, single person households and manufacturing companies who need to feed a great number of people (McCullough et al., 2003). People, who are considered general consumers in the food industry, as specified above, spend less than five minutes on preparing weekday meals at the end of the day (Akers, 1997).

Even though pre-packed or ready-to-eat food products (which are considered as instant food products) are popular in certain areas of Europe and the U.S., it brings up a question if such products can be successfully sold in a market where consumers still prefer to purchase homemade products (Putnam, Allshouse \& Kantor, 2002; Smith, 2003). Introducing and aiming to successfully sell a food product in a new and different culture - such as the traditional Hungarian market - is challenging. Manufacturers and retailers have to face several issues regardless of the attributes of a product. Consumers in a set culture tend to be uncertain and reject products from other unknown or non-introduced countries. The major elements of uncertainty are safety issues, derived pleasure and general taste (Prescott, Young, Zhang \& Cummings, 2004; D'Antuono \& Bignami, 2012). According to these descriptions above, instant food products theoretically might have a cultural barrier in the Hungarian market (Smith, 2003). Therefore this research aimed to identify pre-determined factors that might affect consumer purchase intention towards instant food products, specifically focusing on instant noodle products in the Hungarian market.

\section{ANALYSIS OF RECENT RESEARCH AND PUBLICATIONS}

\section{Consumer Purchase Intention}

Consumer purchase intention is considered to be a willingness or inner drive that is driven by the level of existence of willingness: in other words, intention itself is considered to be a factor that predicts the actual actions of a consumer in the future (Ramayah, Jason, \& Mohamad, 2010). The theoretical nature of the relationship between the impacting factors and purchase intention is considered as a causeeffect relationship and can be measured by the level of willingness to purchase, whether in a positive or negative way. This measurement element has a higher chance of being strong when willingness and inner drive are high and has a high chance of being weak when the willingness and inner drive are low (Francis, Lee, Lin, \& Low, 2012). According to the definitions given above, consumer purchase intention can be measured by positive or negative willingness, which affects purchase intention in either way. When willingness is significantly high, then purchase intention is going to be high as well, therefore there is a significant effect. On the other hand when willingness is significantly low, then purchase intention is going to be low as well. Therefore there is a significant effect (Francis et al., 2012).

\section{Impacting Factors}

The outlook of a product is a key factor for consumers in making a decision to purchase, however the product itself is not being sold without any packaging. Therefore, it is highly important for a product to look attractive (Prendergast and Pitt, 1996). There are two main functions of packaging according to Prendergast and Pitt (1996): one is protection, two is attraction. It is a long way until a prepacked product gets to a shelf in a super- or hypermarket. Therefore, the risk of damaging a product is being reduced by the wrapper, box or whatever form of packaging. On the other hand, as said before, a product needs to sell itself even if there is no approaching marketing strategy in action. Grabbing the attention of a consumer and approaching some sort of a communication is inevitable and can mainly happen through a package. Rettie and Brewer (2000) calls packaging the "the salesman on the shelf" in the 21st century where a high majority of the products only have the chance to communicate 
with customers while they are sitting on a shelf waiting to be sold.

The research of Vermeir and Verbeke (2004) describes consumer purchase intention in the situation when youngsters in the Western European region were examined about their purchase intention towards dairy products which fall into the same category as instant noodle products because of their level of involvement that is discussed below; a decision criteria that takes several factors into consideration. The study points out that the traditional decision criteria that are the most important factors in the process include price, quality and convenience. These factors were found to be the attributes that stand out (among others) to catch customers' attention in the attitude-behavioral gap the study was researching by analyzing consumer attitudes and purchase intention for dairy products.

In their research, Eddyono and Subroto (2014) studied the Indonesian consumer market with the emphasis of finding the most influencing factors of instant noodle purchase behavior. Their study adapted the consumer decision making model from Schiffman, Leon, Kanuk and Wisenblit (2010), where the decision making process is broken into three main phases: input, process and output. Simply explained, the input phase is an introductory one with the marketing mix's 4Ps; the process phase is the actual decision making process with all the factors affecting this process (psychological factors); the output phase is the post-purchase process which is a simple evaluation process from the consumer side. Therefore, Edyyono and Subroto (2014) built their theoretical model based on the belief that perception (including price, promotion, distribution channels and risk) is hypothetically the most influential factor in purchase behavior towards instant noodle products. Their results provide the information that price and risk (health related risks) are not a significant influence in instant noodle purchase decision making; however promotion is a major factor affecting purchase behavior.

In their study, Srinivasan and Nirmalas (2014) concluded that in an average town in India the purchase intention of instant food (mainly instant noodles) increased due to several factors. Their sample $(n=100)$ showed that people in that geographical region where the study was conducted purchase more instant food products because of the change in family structure as single or married, convenience, and the increased income of the middle class. Some of their suggestions to enhance sales from the manufacturer or retailer point of view were distribution of free samples and television and digital advertisements. On the other hand they reported that in 2014 that the prices of instant food products affected consumer purchase behavior negatively. Therefore, their recommendation is to lower sales price to significantly increase sales volume. Srinivasan and Nirmalas' (2014) study accordingly shows similarities in consumer purchase intention factors to Vermeir and Verbeke's (2004) results as convenience together with product price. From these factors, convenience and price are independent variables that might have an effect on purchase intention towards instant noodle products, the dependent variable.

In a nationwide research, Harris and Shiptsova (2007) measured the pre-determined factors in terms of relevance to affect consumer purchase behavior towards convenience foods. The study identified variable factors as follows: income, price, age, marital status and level of education. Out of these hypothetical factors, income and price had a positive effect on consumer purchase behavior. On the other hand marital status and education had negative effects.

The research of Manchester Metropolitan University (McCullough et al., 2003) says that consumer awareness of a healthy diet is higher if they stay in further and higher education longer. This will have an effect on their knowledge of nutrition and positively encourage them to make improved food choices. They also found out in their research $(n=150)$ that 50 per cent of the asked are concerned over eating nutritious food, however only 10 per cent of them indicated that instant snacks (such as snack pots) were nutritionally balanced. Three fourth of the respondents stated that they do not think that ready-to-eat instant foods are good for health because of additives, as well as a high percent of fat and salt; therefore they consider perceived health risk upon purchase. This data should be treated as only partially reliable though, because the research states that some respondents do not believe manufacturers put the valid ingredients on packages and the questioned consumers were not tested about their nutritional knowledge. The respondents' 65 per cent also stated that they never read the content label. 
In the UK market, a consumer research states that instant snacks or ready-to-eat food products are being purchased on a high level and are certainly popular between ages 15-18 years old. However this age group loses interest in the products between 18-22 years of age, which is an interesting trend to see if age is similarly as relevant in Hungary as in the UK because if the cultural similarities (Mintel, 2000c).

Although the definitions above are various they all lead several common views that willingness to purchase, therefore consumer purchase intention is affected by a wide but fairly similar amount of factors. These are packaging, product aspects (price, quality, flavor), perceived health risk, promotion and convenience; and can be impacted by age, gender, marital status, level of education and income.

\section{PRESENTATION OF KEY RESEARCH FINDINGS}

\section{Demographic and socio-economic diversification}

The respondents $(n=386)$ were asked about their age, gender, marital status, level of education and income. The answer choices for age were separated into four categories: still in the education system (18-25 years old), young professionals (26-35 years old), experienced professionals ( $36-50$ years old), elder generation (older than 50 years old). The answer choices for gender were separated into two categories: female and male. The answer choices for marital were separated into two categories: single or married. The answer choices for level of education were separated into five categories based on the Hungarian education system: elementary school (8 years), high school (12 years), vocational certificate/associate's degree, bachelor's degree, master's degree or higher. The answer choices for income were separated into five categories based on Hungarian levels of net salaries: less than 100,000 HUF, between 100,001 HUF and 200,000 HUF, between 200,001 HUF and 300,000 HUF, between 300,001 HUF and 400,000 HUF, more than 400,001 HUF.

The research shows that the weighted average of willingness to purchase instant noodle products for female respondents is higher than neutral and for male respondents it is higher than neutral, but slightly lower than female respondents'.

The research shows that the weighted average of willingness to purchase instant noodle products for $18-25$ years old respondents is higher than neutral, for 26-35 years old respondents it is slightly higher than neutral, for 36-50 years old respondents it is slightly lower than neutral and for older than 50 years old respondents it is strong.

The research shows that the weighted average of willingness to purchase instant noodle products for single respondents is higher than neutral, closer to strong and for married respondents it is lower than neutral.

The research shows that the weighted average of willingness to purchase instant noodle products for respondents who finished elementary school (8 years of education) is strong, for respondents who finished high school (12 years of education) is strong, for respondents earned a vocational degree/associate's degree is higher than neutral, for respondents who earned a bachelor's degree is lower than neutral and for respondents who earned a master's degree or higher is lower than neutral.

The research shows that the weighted average of willingness to purchase instant noodle products for respondents who earn a monthly net income of less than 100,000 HUF is significantly strong, for a monthly net income of $100,001-200,000$ HUF is significantly strong, for respondents a monthly net income of 200,001 300,000 HUF is low, for a monthly net income of $300,001-400,000$ HUF is significantly low and for a monthly net income of more than 400,001 HUF is low.

\section{SUMMARY}

The conducted exploratory factor analysis showed that there are four main components in the research data. The first component contains factors mainly from the independent variables of convenience and promotion. Based on the results, the second component contains factors mainly from the independent variable of product aspects, moreover from the price compared to average dimension. The third component contains factors mainly from the independent variables of promotion and packaging; however this component is not as clear as the others. The fourth component contains factors mainly from the independent 
variable of promotion.

After results were taken from the exploratory factor analysis (EFA) the confirmatory factor analysis (CFA) was conducted with a structural model showing that the willingness to purchase instant noodle products in the Hungarian market is impacted by packaging (appearance), product aspect of price (product price compare to average), promotion (drive, marketing communication) and convenience (decision making process, time spent on preparing food, time spent on shopping).

\section{CONCLUSIONS AND RECOMMENDATIONS}

With the total of 386 complete responses, this research represents one of the first large-scale surveys of the instant noodle market of Hungary. The demographics and socioeconomic factors' results show that regarding the gender break down of the respondents the study can be considered relevant with male being $42 \%$ and female being $58 \%$ of the respondents. The sample reflects the population's gender ratios. The results showed that both male and female respondents have higher than neutral willingness to purchase instant noodle products. Female respondents are 3.3\% higher in willingness to purchase.

As per the age break down, the study collected samples by convenience sampling in several different locations of the geographic area of the population in different timeframes. This was done in order to get a wide range of sample from all segments of the population, whether they do shopping early in the day or later in the day. The results show that close to two-thirds (59\%) of the respondents were below or at the age of 35 , which is not correspondent to the Hungarian Central Statistical Office's (2016) measurements as per the country's population being represented in the sample. They show that most of the population is close to 40 years old or close to 60 years old. This research is distinct from the above measurements which can be explained by several reasons. One, elderly people reporting their age incorrectly (Smit, Deeg, \& Schmand, 1997). Second, even though elders prefer being in contact with younger people (Cybulski, Krajewska-Kułak, Sowa, Orzechowska, Van Damme-Ostapowicz, Rozwadowska, \& Guzowski, 2013) that was not necessarily true when the researcher of this study (being in his twenties) distributed the survey questionnaires. Third, as an experience in this study the researcher found several times that the elder population did not have a clear idea about the subject of the research, namely instant noodle products, therefore were incapable of completing a survey. In terms of showed willingness to purchase instant noodle products, respondents who are older than 50 years showed a strong intention to purchase followed by the youngest age group of 18-25 years old. This might be correlated with monthly net income, which would mean that the general population in Hungary makes the lowest amount of money within these age groups (Nettober.com, 2018).

The marital break down of the research highly correlates with the age range break down by respondents being mainly less than 35 years of age. The Hungarian Central Statistical Office (2014) showed results in the Hungarian population for the average age of citizens of Hungary getting married at 34.4 years of age in highly populated cities. This is a reasonable explanation on the respondents' answer ratios single being $77 \%$ and married being $23 \%$. The results also showed an outcome of significantly higher willingness to purchase instant noodle products within single respondents than married respondents.

The highest level of education ratios show that the research sample reflects the country of Hungary's population highest earned education ratios (Hungarian Central Statistical Office, 2014). The highest level of education ratios also show there is a certain pattern in willingness to purchase instant noodle products that correlates with highest level of education, meaning that the higher the earned education level is within the respondents, the lower the willingness to purchase. This could reflect the knowledge acquired over the years of additional education about fast food, instant and low-involvement food products.

The monthly net income ratios show a certain pattern in terms of respondents' willingness to purchase based on their monthly net income. The Hungarian national average wage (after tax) is 197,500 HUF (Hungarian Central Statistical Office, 2018) which puts $64 \%$ of this research's respondents into a group of net income equal to country average or lower and puts $36 \%$ of the respondents over the country's net average wage per month. As per the pattern regarding respondents' willingness to purchase noodle products, respondents who make less than the 
population's average have significantly high willingness, while respondents who make more than the population's average have significantly low willingness. Another way to interpret the willingness is the higher each group of respondents are in terms of monthly net income, the lower the willingness to purchase instant noodle products is.

Previous studies (Rettie \& Brewer, 2000; Prendergast \& Pitt, 1996) showed results regarding packaging, as it is one of the main factors for consumers when making a purchase decision. Both studies point out that packaging is not just a way of protecting a product but rather raising attention. This research showed results correlating to the previous studies in terms of product appearance being highly correlated to willingness to purchase instant noodle products.

In their research, Vermeir and Verbeke (2004) found that price, quality and convenience are influential factors when consumers purchase dairy products in the Western European region. The results from this research corresponds to the price factor being significant, along with the convenience factor as per decision making process, time spent on preparing food and time spent on shopping. However, quality contradicts the results of Vermeir and Verbeke's (2004) even though the measured items - dairy products and instant noodle products - belong to the same low-involvement food product range.

A similar study conducted by Edyyono and Subroto (2014) that was measuring influential factors toward instant noodle purchases in the Indonesian market found that price and risk are not significant factors which contradicts the results of this research as per price being significantly correlated with purchase intention towards instant noodle products. On the other hand, the results of both studies show that promotion is a major factor affecting purchase behavior.

In addition to the research of Srinivasan and Nirmalas (2014) in the Indian market, this research also found that marital status can be an influential factor of willingness to purchase instant food products. Convenience was another factor the Srinivasan and Nirmalas (2014) study found as an influential factor, which correlates to this study. However the findings of increased income and increased willingness to purchase instant food products are the opposite of the findings of this study.

Based on the research by the Manchester Metropolitan University (McCullough et al., 2003) it is hypothetically expected that consumers who spend more time in higher education are less likely to eat unhealthy food. These findings were not convenient in the matter of this study because perceived health risk as an independent variable was a statistically insignificant factor in terms of influential factors towards willingness to purchase instant noodle products.

In the following section the research briefly concludes that the following factors are found to be impacting the willingness to purchase instant noodle products in the Hungarian market: packaging (appearance), product aspect of price (product price compare to average), promotion (drive, marketing communication) and convenience (decision making process, time spent on preparing food, time spent on shopping). In detail, the findings of these correlations show in practice as follows:

\section{- Packaging(appearance):}

The packaging of instant noodle products in terms of how eye-catching and attractive they are to the consumers' eyes in the Hungarian market is an impact on purchasing intention. These terms were defined as general terms, along with another aspect of written elements on the packaging. In overall, these three aspects together have impact on the purchase intention.

\section{- Product aspect of price (product price compare to average):}

Instant noodle products' price compared to average in terms of the Hungarian consumers' perception of average price has an impact on purchasing decision.

\section{- Promotion (drive, marketing communication):}

Promotion as a variable, including specifically drive of purchase and response to marketing communication as dimensions, has impact on purchase intention towards instant noodle products. In further detail, drive of purchase in general builds up from the aspects of predetermined decision to purchase, existing discounts and on-the-sport purchase. The research found out that all three of these aspects have impact on purchase intention. As per response to marketing communication, the research identifies this factor as the Hungarian consumers' perception of how timely they see 
or notice instant noodle product related advertisements.

- Convenience (decision making process, time spent on preparing food, time spent on shopping):

Convenience as a variable, including specifically time spent for shopping, decision making process and time spent on preparing food as dimensions, has impact on purchase intention towards instant noodle products. In further detail, time spent for shopping consists of short shopping time, visiting of several establishments and convenience shopping as aspects. Decision making process consists of habitual purchase, on-the-spot purchasing and consumers' perception of highest quality. Time spent for preparing food consists of the consumers' perception about instant food products' preparation time, the preparation time of home-cooked meals and convenience shopping.

\section{RECOMMENDATIONS TO BUSINESSES AND MANAGEMENT PROFESSIONALS}

This research found that the willingness to purchase instant noodle products in the Hungarian market is impacted by packaging (appearance), product aspect of price (product price compare to average), promotion (drive, marketing communication) and convenience (decision making process, time spent on preparing food, time spent on shopping). On the other hand, other factors as information on label, portion, quality, flavor, perceived health risk (inappropriate diet, weight gain, sickness), and involvement do not have an impact on willingness to purchase instant noodle products.

Firstly, to attain more knowledge on the impacting factor in the Hungarian market, it is recommended that each of the feasible elements are examined by business sector professionals. For instance the appearance of an instant noodle product's packaging has certain colors and design in certain regions of the world. And since this factor has a major impact on consumers' willingness to purchase, it is recommended to further explore patterns in the Hungarian market. As per the price of the product, it is recommended to management professionals to investigate the competition's price creating patterns and habits in the Hungarian market. The impact of drive of purchase and response to marketing communication suggests that the promotional channels are working well in the Hungarian market, which should be emphasized by corresponding marketing and sales activities to encourage purchasing. Convenience shows to be a main impact along with the previous ones, and suggests that the mentioned sales and marketing activities should be correlated with convenience driven thinking. The research shows that the Hungarian market is led by convenience when it comes to groceries purchases.

Secondly, certain variables that would be taken into consideration as an impact on willingness to purchase instant noodle products are shown not to be relevant in the Hungarian market. For instance the information on the label or portioning of instant noodle products might be a decisive factor in certain regions of the world, but in the Hungarian market, based on this research, it is shown to be the opposite along with flavor, perceived health risk and involvement. This suggests that business professionals should focus less on involving consumers, allocating resources regarding alleged health risk issues, informing thoroughly on packaging more than required, trying to serve multiple needs regarding portions, and beyond exploring flavors.

Lastly, the research concludes that young (less than 35), single, lower educated (elementary school, high school or vocational/associate's degree) and below average or close to average (less than 100,000 HUF and 100,001-200,000 HUF) net earners show the highest willingness to purchase instant noodle products. This consumer profile is recommended to be targeted by business professionals in promotional or convenience channels in order to enhance purchasing of instant noodle products. A product with an appealing outlook and reasonable price at a convenient location for the targeted consumer profile in the Hungarian market has a high chance of resulting in willingness of purchase.

\section{REFERENCES}

Akers, W. (1997). “Geest Prepared Foods”, Taste 200 Press Release, Hammond Communications, London.

Buckley, M., Cowan, C., \& McCarthy, M. (2007) "The Convenience Food Market in Great Britain: Convenience Food Lifestyle (CFL) Segments." Appetite 49: 600-17. 
Cybulski, M., Krajewska-Kułak, E., Sowa, P., Orzechowska, M., Van Damme-Ostapowicz, K., Rozwadowska, E., \& Guzowski, A. (2013). Elderly Peoples' Perception of Young People - A Preliminary Study. Iranian Journal of Public Health, 42(10), pp. 1099-1105.

D’Antuono, L. \& Bignami, C. (2012). “Perception of typical Ukrainian foods among an Italian population", Food Qual., Prefer. 25: pp. 1-8.

Eddyono, F. \& Subroto B. (2014). "Purchase Behavior of Noodles: A Case Study of Effort Primary Food Diversification in Indonesia." International Journal of Science and Technology, Vol. 3 No. 10.

Francis, W. V. N., Lee, M. Y., Lin, X. R., \& Low, S. Y. (2012). A study on the youth attitudes toward purchase green products in Malaysia and Singapore. University Tunku Abdul Rahman.

Harris, J.M. \& R. Shiptsova. (2007) “Consumer Demand for Convenience Foods: Demographics and Expenditures." Journal of Food Distribution Research 38(3): pp. 2236.

Hungarian Central Statistical Office. (2014). Népszámlálás 2011 - 14. A népesség iskolázottsága. Retrieved February 1, 2018, from https://www.ksh.hu/docs/hun/xftp/idoszaki /nepsz2011/nepsz_14_2011.pdf

Hungarian Central Statistical Office. (2016). Population of Hungary. Retrieved October 3, 2016, from

http://www.ksh.hu/interaktiv/terkepek/mo/ nepesseg.html

Hungarian Central Statistical Office. (2016). Population of Hungary by gender. Retrieved October 3, 2016, from https://www.ksh.hu/interaktiv/korfak/orsza g.html

Hungarian Central Statistical Office. (2018, February 20). Keresetek, 2017. januárdecember. Retrieved February 21, 2018, from https://www.ksh.hu/docs/hun/xftp/gyor/ker /ker1712.html

Krejcie, R. V. \& Morgan, D. W., (1970). "Determining Sample Size for Research Activities", Educational and Psychological Measurement, 1970.

McCullough, F., Jones, S. \& Vignali, D. (2003),"The pot snack market - are today's consumers demanding health as well as convenience?", British Food Journal, Vol. 105 Iss 6 pp. 395 404

Mintel, (2000c), “Supermarketing”, Mintel International Group Ltd., London.

Nettober.com. (2018, February). Anonim fizetésfelmérés - eredmények. Retrieved February 1, 2018,from https://www.nettober.com/index.php?p=fiz etesfelmeres_eredmenyek\&k=eletkor

Pleasanton (1999), “Consumer snacking trends reflect busy lifestyles". Nutrition \& Food Science, Vol. 31 No. 3, p. 8.

Prendergast, P.G. \& Pitt, L. (1996), “Packaging, marketing, logistics and the environment: are there trade-offs?", International Journal of Physical Distribution \& Logistics Management, Vol. 26 No. 6, pp. 60-72.

Prescott, J., Young, O., Zhang, S. \& Cummings, T. (2004) "Effects of added "flavor principles" on liking and familiarity of a sheepmeat product: A comparison of Singaporean and New Zealand consumers.", Food Qual. Prefer. 15: pp. 187-194.

Putnam, J., Allshouse, J., \& Kantor, L. S. (2002). U.S. Per Capita Food Supply Trends: More Calories, Refined Carbohydrates, and Fats. FoodReview, 25(3), 2-15. Retrieved February 24, 2017, from

https://books.google.hu/books?hl=en\&lr=\&i $\mathrm{d}=\mathrm{qJ} J$ wPabe_ysC\&oi=fnd\&pg=PA2\&dq=insta nt food consumption us\&ots=HTo5xCSlep\&sig=dewK41YNZPyvjL6 2zuiPK7kznbE\&redir_esc=y\#v=onepage\&q\&f $=$ false.

Ramayah, T., Jason, L. W. C., \& Mohamad, O. (2010). Green product purchase intention: Some insights from a developing country. Resources, Conservation and Recycling, 54, pp. 1419-1427.

Rettie, R. \& Brewer, C. (2000), "The verbal and visual components of package design", Journal of Product \& Brand Management, Vol. 9 No. 1, pp. 56-70.

Schiffman, L., Leon, G., Kanuk L. L. \& Wisenblit, K. J. (2010). Consumen Behavior. Tenth Edition. New Jersey: Prentice Hall. Inc.

Smit, J. H., Deeg, D. J., \& Schmand, B. A. (1997). Asking the age question in elderly populations: a reverse record check study. The Journals of Gerontology Series B: Psychological Sciences and Social Sciences, 52(4), pp. 175-P177. 
Smith, J. (2003), "From Hazi to Hyper Market: Discources on time, money, and food in Hungary", Anthropology of East Europe Review, Vol. 21 No. 1.

Srinivasan, K. \& Nirmalas, R. (2014) "A Study on Consumer Behavior towards Instant Food Products (With Special References to Kanchipurm Town)". Journal of Business and Management (IOSR-JBM), Vol. 16 No. 11, pp. 17-21.

Vermeir, I. \& Verbeke, W. (2004), “Sustainable food consumption: exploring the consumer "attitude - behavioral intention" gap," Journal of Agricultural and Environmental Ethics(2006) 19: pp. 169-194.

\section{ABOUT THE AUTHOR}

Csaba Nagy: csabajnagy91@gmail.com

Mr. Csaba Janos Nagy is a teacher at NIVA American International School in Bangkok, Thailand. His academic work focuses on international business management with emphasis on global marketing. Before teaching at NIVA American International School, Mr. Csaba worked in several European countries, USA, and in various countries of Persian Gulf region. He earned a Bachelor of Science in sport management from Eszterhazy Karoly University of Eger and a Master of Business Administration from University of the Thai Chamber of Commerce in Bangkok. 